\title{
Oxidative stress and hepatocarcinogenesis
}

\author{
Ying Fu', Fung-Lung Chung ${ }^{2}$ \\ ${ }^{1}$ Laboratory of Molecular Biology, Center for Cancer Research, NCI, Bethesda, MD 20892, USA. \\ ${ }^{2}$ Lombardi Comprehensive Cancer Center, Georgetown University, Washington, DC 20007, USA.
}

Correspondence to: Dr. Ying Fu, Laboratory of Molecular Biology, Center for Cancer Research, NCl, Bethesda, MD 20892, USA. E-mail: ying.fu@nih.gov; Dr. Fung-Lung Chung, Lombardi Comprehensive Cancer Center, Georgetown University, Washington, DC 20007, USA. E-mail: flc6@georgetown.edu

How to cite this article: Fu Y, Chung FL. Oxidative stress and hepatocarcinogenesis. Hepatoma Res 2018;4:39. http://dx.doi.org/10.20517/2394-5079.2018.29

Received: 24 Mar 2018 First Decision: 5 Jul 2018 Revised: 12 Jul 2018 Accepted: 13 Jul 2018 Published: 1 Aug 2018

Science Editor: Guang-Wen Cao Copy Editor: Jun-Yao Li Production Editor: Huan-Liang Wu

\begin{abstract}
Hepatocellular carcinoma (HCC) is the second leading cause of cancer-related deaths worldwide. There are two major challenges for HCC, the first being that early detection is generally not applicable, and secondly, it is usually fatal within several months after diagnosis. HCC is an inflammation-induced cancer. It is known that chronic inflammation leads to oxidative/nitrosative stress and lipid peroxidation, generating excess oxidative stress, together with aldehydes which can react with DNA bases to form promutagenic DNA adducts. In this review, the evidence between oxidative stress and liver carcinogenesis is summarized. We focused on the potential of using DNA adducts as oxidative stress biomarkers for liver carcinogenesis.
\end{abstract}

Keywords: Oxidative stress, DNA adduct, hepatocellular carcinoma, prevention, hepatocarcinogenesis

\section{INTRODUCTION}

Hepatocellular carcinoma (HCC) is the second leading cause of cancer-related deaths worldwide, because of late diagnosis and poor therapeutic outcome ${ }^{[1-4]}$. HCC accounts for $5.5 \%$ of all cancer cases globally, and particularly the incidence of HCC has been increasing in the US since the $1980 \mathrm{~s}^{[5,6]}$. The incidence of HCC strongly correlates with liver inflammation from exposure to one or several risk factors including hepatitis B virus (HBV), hepatitis $\mathrm{C}$ virus (HCV), inherited metabolic diseases, heavy alcohol exposure, obesity, type 2 diabetes and aflatoxins ${ }^{[7-13]}$.

In this review, we will mainly discuss the role of oxidative stress in hepatocarcinogenesis. The search for reliable biomarkers for liver cancer has been executed in different areas: DNA methylation, genomics, pro-

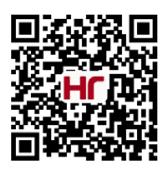


teomics, microRNA and liquid biopsy ${ }^{[14-20]}$. We want to highlight that promutagenic DNA adducts is a new field which need further investigations in the search of biomarkers for HCC.

\section{HEPATATOCARCINOGENESIS AND OXIDATIVE STRESS}

More than $90 \%$ of HCCs arise in the context of hepatic inflammation ${ }^{[21-29]}$. Chronic liver inflammation leads to oxidative/nitrosative stress and lipid peroxidation (LPO), generating excess reactive oxygen species (ROS) and reactive nitrogen species (RNS), together with aldehydes which can react with DNA bases to form promutagenic DNA adducts through either endogenous or exogenous insults ${ }^{[30]}$. Oxidative stress has been demonstrated as an important factor to carcinogenesis since the first experiment on ROS-induced transformation of mouse fibroblast cells in the $1980 \mathrm{~s}^{[31]}$. It has emerged as an important player in the development and progression of liver carcinogenesis for different etiologies (e.g., HBV- and HCV- induced liver diseases) ${ }^{[32]}$. HCC incidences in the USA are largely associated with HCV-related cirrhosis, but changes observed by epidemiological studies have attributed obesity and diabetes as risk factors as well ${ }^{[33]}$. The increased oxidative stress in obesity and diabetes may play a crucial role in hepatatocarcinogenesis ${ }^{[34,35]}$. Because oxidative stress drives genomic damage and genetic instability to cause mutations, and mutations play a crucial role in carcinogeneisis. This notion is supported by the chemopreventive effect demonstrated in a large number of epidemiology studies on the relationship of high fruit and, vegetable consumption with low cancer incidences, among which, antioxidants effects and maintenance of normal DNA repair capacity are indicated to be two crucial mechanisms of actions ${ }^{[36,37]}$. The same concept was illustrated when knocking out antioxidant defenses significantly increased the rate of liver cancer, e.g., knock-out mice lacking CuZuSOD (copperzinc superoxide dismutase) are found to increase liver carcinogenesis ${ }^{[38]}$. Another mouse model showed that knocking out nuclear respiratory factor-1 (Nrf1), an essential transcription for mediating oxidative stress, induces steatosis, fibrosis and liver cancer, eventually ${ }^{[39]}$.

The notion that oxidative stress induces HCC is also supported by studies on hemochromatosis. A positive correlation between mild/excess iron deposition and HCC in patients with hemochromatosis suggests a possible carcinogenic role for oxidative stress induced by iron through Fenton reactions ${ }^{[40,41]}$. In the iron-nitrilotriacetic acid rat model of hemochromatosis, elevated genotoxic products from oxidative stress, 4-hydroxyl-2nonenal (HNE) and malondialdehyde (MDA), are found ${ }^{[42]}$. This increase is also accompanied by damaged cellular defense system, for instance, vitamin E level, GSH/GSSG ratio and superoxide dismutase are all decreased. HNE has the potential to damage genomic DNA and cause mutations, e.g., HNE adduct has been demonstrated to cause p53 mutations which are associated with more than $50 \%$ of HCC incidences ${ }^{[43]}$. A more important link was discovered in patients with hemochromatosis who suffered iron overload and p53 mutations following HCC development ${ }^{[41,4-46]}$; it suggests that oxidative stress is an underlying mechanism of HCC carcinogenesis ${ }^{[44]}$. The role of oxidative stress in liver carcinogenesis is also supported by the result of a multicenter study: using tissue microarray screening, cytochrome P450 1A2 (CYP1A2) oxidase in noncancerous tissue is found and validated as the only predictive factor for HCC recurrence ${ }^{[47]}$.

Oxidative stress is a crucial factor in the initiation and progression of HCC under various pathological conditions ${ }^{[48]}$. Oxidative stress can be induced by ROS produced in the mitochondria in non-alcoholic fatty liver disease, which damages hepatocytes, promotes pathologic polyploidization, triggers inflammation, and contributes to insulin resistance ${ }^{[49-53]}$. Additionally, oxidative stress is also involved in migration, invasion, and metastasis of $\mathrm{HCC}^{[54-56]}$. In that, biomarkers of oxidative stress can predict HCC risk and also the recurrence of HCC. Quantitative methods for the evaluation of oxidative stress can be divided into three categories: (1) determination of compounds modified by oxidative stress; (2) determination of the activity of antioxidant enzymes; and (3) determination of oxidative stress indicators containing transcription factors. Serum quantification of derivatives of reactive oxygen metabolites (d-ROM) level, a simple method for measuring hydrogen peroxide, is found to predict the risk of HCC recurrence after surgical resection or radiofrequency 
ablation $(\mathrm{RFA})^{[57]}$. Since cancer is a genetic disease, we think that mutagenic DNA adducts that arise from oxidative stress have the potential to serve as more direct and precise biomarkers to predict HCC risk and recurrence. A major oxidative stress and promutagenic DNA adduct, 8-oxo-7, 8-dihydro-2'-deoxyguanosine (8-oxo-dG), was found to be increased during hepatocarcinognesis. It suggests a role of mutagenic DNA lesions in HCC formation ${ }^{[8,59]}$. In an HCV/HCC clinical trial, the result supports the hypothesis that HCV induces inflammation that causes oxidative DNA damage (increase of 8-oxo-dG, a DNA lesion), and promotes hepatocarcinogenesis.

LPO induced DNA adducts, including various propano- and etheno- adducts, have been investigated as potential lead markers for various types of inflammatory/oxidative stress cancer-prone diseases (e.g., chronic pancreatitis, Crohn's disease, ulcerative colitis, alcohol related hepatitis, H. pylori infection) and cancer initiation/promotion ${ }^{[60,61]}$. It is also known that the propano DNA adducts [e.g., $\gamma$-hydroxy-1, $N^{2}$ propanodeoxyguanosine $(\gamma-\mathrm{OHPdG})]$ arisen from lipid peroxidation are mutagenic and associated with liver cancinogenesis $^{[62]}$. The levels of propano DNA lesions are the balance of oxidative stress induced LPO and DNA repair. Nucleotide excision repair (NER) pathway is mainly responsible for repairing these bulky DNA adducts $^{[43,63,64]}$. Patients with HBV may exhibit inefficiency of removing bulky DNA adducts because HBx protein has been shown to inhibit NER pathways through suppressing XPB and XPD helicases [transcription factor IIH (TFIIH) ${ }^{[65]}$. We reason that DNA adducts possibly play a role of causing mutations by HBV, but further testing should be done to prove this hypothesis.

$\gamma$-OHPdG is an endogenous product of acrolein, a reactive aldehyde generated by $\mathrm{LPO}^{[66]} \cdot \gamma$-OHPdG is known to cause $\mathrm{G}$ to $\mathrm{T}$ and $\mathrm{G}$ to $\mathrm{A}$ mutations that may involve critical genes such as $p 53^{[67-70]}$. Our recent studies demonstrated an association of the levels of $\gamma$-OHPdG with HCC development in a NER deficient mouse model with spontaneous HCC development. It is also found that antioxidants can suppress $\gamma$-OHPdG and prevent liver cancer significantly ${ }^{[71,72]}$. Further analysis found that GC>TA mutation is the dominant alteration, accounting for approximately $90 \%$ of mutations. The high GC>TA mutation frequency implies that $\gamma$-OHPdG may play a role in the mutagenesis of HCC development ${ }^{[71,72]}$. Understanding the role of DNA adducts of lipid peroxidation and the repair pathways involved may shed light onto mutagenesis during HCC development, and this knowledge will help us to find a way to its prevention ${ }^{[73]}$. To our knowledge, there is still no clinical data regarding LPO-derived DNA adducts as a predictive biomarker for HCC risk, we hope the ongoing interventional multi-center clinical trial "defined green tea catechin extract in preventing liver cancer in patients with cirrhosis (NCT03278925)” will shed some light on $\gamma$-OHPdG as a biomarker for liver carcinogenesis.

Thanks to recent advances in imaging modalities and the prevalence of a surveillance method for HCC, an increasing proportion of patients now receive local ablation therapy or curable resection. However, the high annual recurrence rate (approximately 20\%) is still a huge hurdle before achieving long-term disease-free survival ${ }^{[74]}$. Neoadjuvant and adjuvant therapy for resectable HCC is still a difficult challenge. There are two major postoperative recurrence mechanisms: de novo carcinogenesis (usually late recurrence) and metastatic recurrence (usually occurs within one year and is related to intrahepatic metastasis) ${ }^{[75]}$. Precise prevention strategies are needed to target these mechanisms ${ }^{[76]}$. Three major strategies have been developed to address this issue ${ }^{[77]}$. The first one is a virus eradication method using interferon. But this method is not going to rescue the hepatocytes which have been damaged by hepatitis virus ${ }^{[78]}$. The second strategy is the use of anticancer drugs. Difficulties have been reported in the STROM trial (sorafenib as adjuvant treatment in the prevention of recurrence of hepatocellular carcinoma) and with the use of UFT (Tegafur-uracil) ${ }^{[79]}$. The last strategy is to induce differentiation of liver cancer cells. For example, using Pertinoin, an acyclic retinoid which can induce apoptosis and differentiation of cancer cells. This method has shown promising survival beneficial effects in a clinical phase II trial. Other than these strategies, branched chain amino-acid supplementation, vitamin $\mathrm{K} 2$ and acyclic retinoid have also been examined ${ }^{[80]}$. The reality is that no chemopreven- 


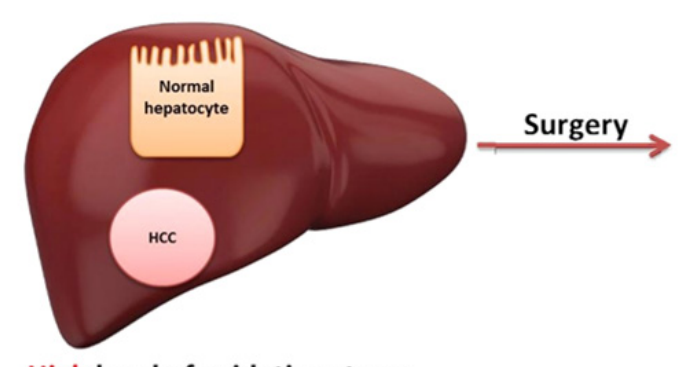

High level of oxidative stress

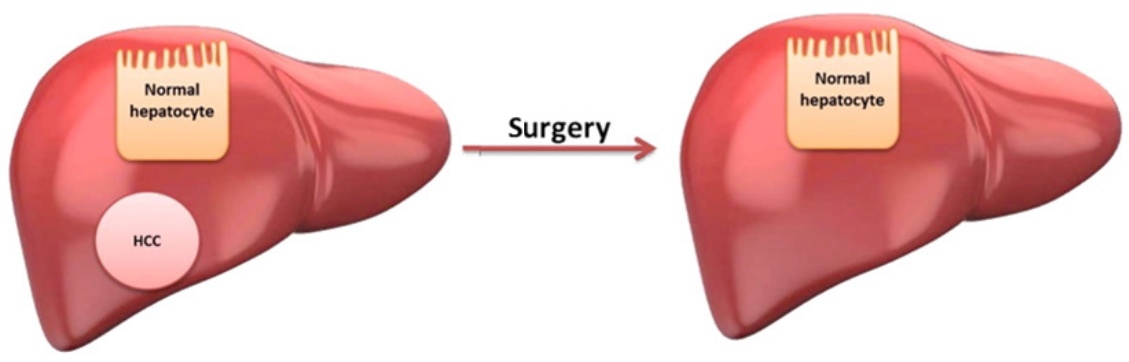

Low level of oxidative stress

Figure 1. Oxidative stress and liver recurrence after surgery. HCC: hepatocellular carcinoma

tive agent has been approved by FDA against HCC recurrence. There is still a lot of effort to be made to win this war against HCC recurrence. Future design may require focus on combination therapy. For instance, vitamin $\mathrm{K} 2$ and angiotensin-converting enzyme inhibitor have shown suppression effect on cumulative recurrence of HCC after curative therapy partially through reducing VEGF-mediated neovascularization ${ }^{[81]}$.

\section{FUTURE PERSPECTIVES}

Clinical trials using oxidative stress biomarkers for HCC and predicting HCC recurrence after curable surgery have been conducted [Figure 1]. Multi-center trials should be carried out to prove this application. The link between oxidative stress, DNA adducts, mutations, and cancer needs to be systematically studied; it is an area of study that can be accelerated by emerging technologies (e.g., next generation sequencing, Chipseq, and SMART sequencing ${ }^{[82]}$ ). New technologies are needed to demonstrate in real-time link between exact DNA lesion sites (from normal tissue) and mutations (from tumor tissue). The idea of using antioxidants to prevent HCC recurrence has yet to be fully tested ${ }^{[83-85]}$. Use of oxidative stress markers to guide these trials warrants future investigation.

\section{DECLARATIONS}

\section{Acknowledgments}

We thank Dr. Aiwu Ruth He for discussions when preparing this review. The authors also thank Cindy Clark, NIH Library Writing Center, for manuscript editing assistance.

\section{Authors' contributions}

Design of the review: Fu Y, Chung FL

Literature review and manuscript writing: Fu Y, Chung FL

Manuscript revision: Fu Y, Chung FL

\section{Availability of data and materials}

Not applicable. 


\section{Financial support and sponsorship}

National Cancer Institute (R01-CA-190678, to Chung FL), the NCI Director's Challenge Innovation Award (to $\mathrm{Fu}$ Y) and ONYX Pharmaceuticals Research Award (to Fu Y).

\section{Conflicts of interest}

The authors declare that there are no conflicts of interest.

\section{Ethical approval and consent to participate}

Not applicable.

\section{Consent for publication}

Not applicable.

\section{Copyright}

(c) The Author(s) 2018.

\section{REFERENCES}

1. Reig M, Marino Z, Perello C, Inarrairaegui M, Ribeiro A, Lens S, Diaz A, Vilana R, Darnell A, Varela M, Sangro B, Calleja JL, Forns X, Bruix J. Unexpected high rate of early tumor recurrence in patients with HCV-related HCC undergoing interferon-free therapy. J Hepatol 2016;65:719-26.

2. Lencioni R, Llovet JM, Han G, Tak WY, Yang J, Guglielmi A, Paik SW, Reig M, Kim DY, Chau GY, Luca A, Del Arbol LR, Leberre MA, Niu W, Nicholson K, Meinhardt G, Bruix J. Sorafenib or placebo plus TACE with doxorubicin-eluting beads for intermediate stage HCC: the SPACE trial. J Hepatol 2016;64:1090-8.

3. Hoffmann K, Glimm H, Radeleff B, Richter G, Heining C, Schenkel I, Zahlten-Hinguranage A, Schirrmacher P, Schmidt J, Büchler MW, Jaeger D, von Kalle C, Schemmer P. Prospective, randomized, double-blind, multi-center, Phase III clinical study on transarterial chemoembolization (TACE) combined with Sorafenib versus TACE plus placebo in patients with hepatocellular cancer before liver transplantation - HeiLivCa [ISRCTN24081794]. BMC Cancer 2008;8:349.

4. Wang FS, Fan JG, Zhang Z, Gao B, Wang HY. The global burden of liver disease: the major impact of China. Hepatology 2014;60:2099108.

5. Rahib L, Smith BD, Aizenberg R, Rosenzweig AB, Fleshman JM, Matrisian LM. Projecting cancer incidence and deaths to 2030: the unexpected burden of thyroid, liver, and pancreas cancers in the United States. Cancer Res 2014;74:2913-21.

6. Ryerson AB, Eheman CR, Altekruse SF, Ward JW, Jemal A, Sherman RL, Henley SJ, Holtzman D, Lake A, Noone AM, Anderson RN, Ma J, Ly KN, Cronin KA, Penberthy L, Kohler BA. Annual Report to the Nation on the Status of Cancer, 1975-2012, featuring the increasing incidence of liver cancer. Cancer 2016;122:1312-37.

7. Camma C, Cabibbo G, Craxi A. Direct antiviral agents and risk for HCC early recurrence: much ado about nothing. J Hepatol 2016;65:8612 .

8. Umemura A, He F, Taniguchi K, Nakagawa H, Yamachika S, Font-Burgada J, Zhong Z, Subramaniam S, Raghunandan S, Duran A, Linares JF, Reina-Campos M, Umemura S, Valasek MA, Seki E, Yamaguchi K, Koike K, Itoh Y, Diaz-Meco MT, Moscat J, Karin M. p62, upregulated during preneoplasia, induces hepatocellular carcinogenesis by maintaining survival of stressed HCC-initiating cells. Cancer Cell 2016;29:935-48.

9. Ozer Etik D, Suna N, Boyacioglu AS. Management of hepatocellular carcinoma: prevention, surveillance, diagnosis, and staging. Exp Clin Transplant 2017;15:31-5.

10. Oishi N, Yamashita T, Kaneko S. Molecular biology of liver cancer stem cells. Liver Cancer 2014;3:71-84.

11. Xue W, Chen S, Yin H, Tammela T, Papagiannakopoulos T, Joshi NS, Cai W, Yang G, Bronson R, Crowley DG, Zhang F, Anderson DG, Sharp PA, Jacks T. CRISPR-mediated direct mutation of cancer genes in the mouse liver. Nature 2014;514:380-4.

12. Eggert T, Wolter K, Ji J, Ma C, Yevsa T, Klotz S, Medina-Echeverz J, Longerich T, Forgues M, Reisinger F, Heikenwalder M, Wang XW, Zender L, Greten TF. Distinct functions of senescence-associated immune responses in liver tumor surveillance and tumor progression. Cancer Cell 2016;30:533-47.

13. Jang JW, Choi JY, Bae SH, Kim CW, Yoon SK, Cho SH, Yang JM, Ahn BM, Lee CD, Lee YS, Chung KW, Sun HS. Transarterial chemolipiodolization can reactivate hepatitis B virus replication in patients with hepatocellular carcinoma. J Hepatol 2004;41:427-35.

14. Yoon SK, Lim NK, Ha SA, Park YG, Choi JY, Chung KW, Sun HS, Choi MJ, Chung J, Wands JR, Kim JW. The human cervical cancer oncogene protein is a biomarker for human hepatocellular carcinoma. Cancer Res 2004;64:5434-41.

15. Zinkin NT, Grall F, Bhaskar K, Otu HH, Spentzos D, Kalmowitz B, Wells M, Guerrero M, Asara JM, Libermann TA, Afdhal NH. Serum proteomics and biomarkers in hepatocellular carcinoma and chronic liver disease. Clin Cancer Res 2008;14:470-7.

16. Ji JF, Shi J, Budhu A, Yu ZP, Forgues M, Roessler S, Ambs S, Chen Y, Meltzer PS, Croce CM, Qin LX, Man K, Lo CM, Lee J, Ng IO, Fan J, Tang ZY, Sun HC, Wang XW. MicroRNA expression, survival, and response to interferon in liver cancer. N Engl J Med 2009;361:143747.

17. Jia HL, Ye QH, Qin LX, Budhu A, Forgues M, Chen Y, Liu YK, Sun HC, Wang L, Lu HZ, Shen F, Tang ZY, Wang XW. Gene expression 
profiling reveals potential biomarkers of human hepatocellular carcinoma. Clin Cancer Res 2007;13:1133-9.

18. Beale G, Chattopadhyay D, Gray J, Stewart S, Hudson M, Day C, Trerotoli P, Giannelli G, Manas D, Reeves H. AFP, PIVKAII, GP3, SCCA-1 and follisatin as surveillance biomarkers for hepatocellular cancer in non-alcoholic and alcoholic fatty liver disease. BMC Cancer 2008;8:200.

19. Li LM, Hu ZB, Zhou ZX, Chen X, Liu FY, Zhang JF, Shen HB, Zhang CY, Zen K. Serum microRNA profiles serve as novel biomarkers for HBV infection and diagnosis of HBV-positive hepatocarcinoma. Cancer Res 2010;70:9798-807.

20. Labgaa I, Villanueva A. Liquid biopsy in liver cancer. Discov Med 2015;19:263-73.

21. Yang JD, Roberts LR. Hepatocellular carcinoma: a global view. Nat Rev Gastroenterol Hepatol 2010;7:448-58.

22. Starley BQ, Calcagno CJ, Harrison SA. Nonalcoholic fatty liver disease and hepatocellular carcinoma: a weighty connection. Hepatology 2010;51:1820-32.

23. Ande SR, Nguyen KH, Gregoire Nyomba BL, Mishra S. Prohibitin-induced, obesity-associated insulin resistance and accompanying lowgrade inflammation causes NASH and HCC. Sci Rep 2016;6:23608.

24. Shalapour S, Karin M. Fatty acid-induced T cell loss greases liver carcinogenesis. Cell Metab 2016;23:759-61.

25. Galun E. Liver inflammation and cancer: the role of tissue microenvironment in generating the tumor-promoting niche (TPN) in the development of hepatocellular carcinoma. Hepatology 2016;63:159-68.

26. He G, Karin M. NF-кB and STAT3-key players in liver inflammation and cancer. Cell Res 2011;21:354-6.

27. Qiao L, Li X. Role of chronic inflammation in cancers of the gastrointestinal system and the liver: where we are now. Cancer Lett 2014;345:150-2.

28. Bishayee A. The role of inflammation in liver cancer. Adv Exp Med Biol 2014;816:401-35.

29. Nikolaou K, Sarris M, Talianidis I. Molecular pathways: the complex roles of inflammation pathways in the development and treatment of liver cancer. Clin Cancer Res 2013;19:2810-6.

30. Bartsch H, Nair J. Chronic inflammation and oxidative stress in the genesis and perpetuation of cancer: role of lipid peroxidation, DNA damage, and repair. Langenbecks Arch Surg 2006;391:499-510.

31. Kensler TW, Trush MA. Role of oxygen radicals in tumor promotion. Environ Mutagen 1984;6:593-616.

32. Marra M, Sordelli IM, Lombardi A, Lamberti M, Tarantino L, Giudice A, Stiuso P, Abbruzzese A, Sperlongano R, Accardo M, Agresti M, Caraglia M, Sperlongano P. Molecular targets and oxidative stress biomarkers in hepatocellular carcinoma: an overview. J Transl Med 2011;9:171.

33. Caldwell SH, Crespo DM, Kang HS, Al-Osaimi AM. Obesity and hepatocellular carcinoma. Gastroenterology 2004;127:S97-103.

34. Matsuzawa-Nagata N, Takamura T, Ando H, Nakamura S, Kurita S, Misu H, Ota T, Yokoyama M, Honda M, Miyamoto K, Kaneko S. Increased oxidative stress precedes the onset of high-fat diet-induced insulin resistance and obesity. Metabolism 2008;57:1071-7.

35. Furukawa S, Fujita T, Shimabukuro M, Iwaki M, Yamada Y, Nakajima Y, Nakayama O, Makishima M, Matsuda M, Shimomura I. Increased oxidative stress in obesity and its impact on metabolic syndrome. J Clin Invest 2004:114:1752-61.

36. Steinmetz KA, Potter JD. Vegetables, fruit, and cancer prevention: a review. J Am Diet Assoc 1996;96:1027-39.

37. Block G, Patterson B, Subar A. Fruit, vegetables, and cancer prevention - a review of the epidemiologic evidence. Nutr Cancer 1992;18:129.

38. Halliwell B. Oxidative stress and cancer: have we moved forward? Biochem J 2007;401:1-11.

39. Xu Z, Chen L, Leung L, Yen TS, Lee C, Chan JY. Liver-specific inactivation of the Nrf1 gene in adult mouse leads to nonalcoholic steatohepatitis and hepatic neoplasia. Proc Natl Acad Sci U S A 2005;102:4120-5.

40. Ko C, Siddaiah N, Berger J, Gish R, Brandhagen D, Sterling RK, Cotler SJ, Fontana RJ, McCashland TM, Han SH, Gordon FD, Schilsky ML, Kowdley KV. Prevalence of hepatic iron overload and association with hepatocellular cancer in end-stage liver disease: results from the National Hemochromatosis Transplant Registry. Liver Int 2007;27:1394-401.

41. Marrogi AJ, Khan MA, van Gijssel HE, Welsh JA, Rahim H, Demetris AJ, Kowdley KV, Hussain SP, Nair J, Bartsch H, Okby N, Poirier $\mathrm{MC}$, Ishak KG, Harris CC. Oxidative stress and p53 mutations in the carcinogenesis of iron overload-associated hepatocellular carcinoma. J Natl Cancer Inst 2001;93:1652-5.

42. Houglum K, Filip M, Witztum JL, Chojkier M. Malondialdehyde and 4-hydroxynonenal protein adducts in plasma and liver of rats with iron overload. J Clin Invest 1990;86:1991-8.

43. Hu W, Feng Z, Eveleigh J, Iyer G, Pan J, Amin S, Chung FL, Tang MS. The major lipid peroxidation product, trans-4-hydroxy-2nonenal, preferentially forms DNA adducts at codon 249 of human p53 gene, a unique mutational hotspot in hepatocellular carcinoma. Carcinogenesis 2002;23:1781-9.

44. Hussain SP, Raja K, Amstad PA, Sawyer M, Trudel LJ, Wogan GN, Hofseth LJ, Shields PG, Billiar TR, Trautwein C, Hohler T, Galle PR, Phillips DH, Markin R, Marrogi AJ, Harris CC. Increased p53 mutation load in nontumorous human liver of wilson disease and hemochromatosis: oxyradical overload diseases. Proc Natl Acad Sci U S A 2000;97:12770-5.

45. Vautier G, Bomford AB, Portmann BC, Metivier E, Williams R, Ryder SD. p53 mutations in british patients with hepatocellular carcinoma: clustering in genetic hemochromatosis. Gastroenterology 1999;117:154-60.

46. Wang XW, Hussain SP, Huo TI, Wu CG, Forgues M, Hofseth LJ, Brechot C, Harris CC. Molecular pathogenesis of human hepatocellular carcinoma. Toxicology 2002;181-182:43-7.

47. Tanaka S, Mogushi K, Yasen M, Ban D, Noguchi N, Irie T, Kudo A, Nakamura N, Tanaka H, Yamamoto M, Kokudo N, Takayama T, Kawasaki S, Sakamoto M, Arii S. Oxidative stress pathways in noncancerous human liver tissue to predict hepatocellular carcinoma recurrence: a prospective, multicenter study. Hepatology 2011;54:1273-81.

48. Sasaki Y. Does oxidative stress participate in the development of hepatocellular carcinoma? J Gastroenterol 2006;41:1135-48.

49. Paradies G, Paradies V, Ruggiero FM, Petrosillo G. Oxidative stress, cardiolipin and mitochondrial dysfunction in nonalcoholic fatty liver disease. World J Gastroenterol 2014;20:14205-18.

50. Gentric G, Maillet V, Paradis V, Couton D, L’Hermitte A, Panasyuk G, Fromenty B, Celton-Morizur S, Desdouets C. Oxidative stress 
promotes pathologic polyploidization in nonalcoholic fatty liver disease. J Clin Invest 2015;125:981-92.

51. Satapati S, Kucejova B, Duarte JA, Fletcher JA, Reynolds L, Sunny NE, He T, Nair LA, Livingston KA, Fu X, Merritt ME, Sherry AD, Malloy CR, Shelton JM, Lambert J, Parks EJ, Corbin I, Magnuson MA, Browning JD, Burgess SC. Mitochondrial metabolism mediates oxidative stress and inflammation in fatty liver. J Clin Invest 2015;125:4447-62.

52. Cichoz-Lach H, Michalak A. Oxidative stress as a crucial factor in liver diseases. World J Gastroenterol 2014;20:8082-91.

53. Polimeni L, Del Ben M, Baratta F, Perri L, Albanese F, Pastori D, Violi F, Angelico F. Oxidative stress: new insights on the association of non-alcoholic fatty liver disease and atherosclerosis. World J Hepatol 2015;7:1325-36.

54. Meyskens FL, Buckmeier JA, McNulty SE, Tohidian NB. Activation of nuclear factor-kappa B in human metastatic melanoma cells and the effect of oxidative stress. Clin Cancer Res 1999;5:1197-202.

55. Brown NS, Bicknell R. Hypoxia and oxidative stress in breast cancer. Oxidative stress: its effects on the growth, metastatic potential and response to therapy of breast cancer. Breast Cancer Res 2001;3:323-7.

56. Toyokuni S, Okamoto K, Yodoi J, Hiai H. Persistent oxidative stress in cancer. FEBS Lett 1995;358:1-3.

57. Suzuki Y, Imai K, Takai K, Hanai T, Hayashi H, Naiki T, Nishigaki Y, Tomita E, Shimizu M, Moriwaki H. Hepatocellular carcinoma patients with increased oxidative stress levels are prone to recurrence after curative treatment: a prospective case series study using the d-ROM test. J Cancer Res Clin Oncol 2013;139:845-52.

58. Jungst C, Cheng B, Gehrke R, Schmitz V, Nischalke HD, Ramakers J, Schramel P, Schirmacher P, Sauerbruch T, Caselmann WH. Oxidative damage is increased in human liver tissue adjacent to hepatocellular carcinoma. Hepatology 2004;39:1663-72.

59. Maki A, Kono H, Gupta M, Asakawa M, Suzuki T, Matsuda M, Fujii H, Rusyn I. Predictive power of biomarkers of oxidative stress and inflammation in patients with hepatitis C virus-associated hepatocellular carcinoma. Ann Surg Oncol 2007;14:1182-90.

60. Bartsch H, Nair J. Oxidative stress and lipid peroxidation-derived DNA-lesions in inflammation driven carcinogenesis. Cancer Detect Prev 2004;28:385-91.

61. Nair U, Bartsch H, Nair J. Lipid peroxidation-induced DNA damage in cancer-prone inflammatory diseases: a review of published adduct types and levels in humans. Free Radic Biol Med 2007;43:1109-20.

62. Fu Y, Nath RG, Dyba M, Cruz IM, Pondicherry SR, Fernandez A, Schultz CL, Yang P, Pan J, Desai D, Krzeminski J, Amin S, Christov PP, Hara Y, Chung FL. In vivo detection of a novel endogenous etheno-DNA adduct derived from arachidonic acid and the effects of antioxidants on its formation. Free Radic Biol Med 2014;73:12-20.

63. Choudhury S, Pan J, Amin S, Chung FL, Roy R. Repair kinetics of trans-4-hydroxynonenal-induced cyclic 1,N(2)-propanodeoxyguanine DNA adducts by human cell nuclear extracts. Biochemistry 2004;43:7514-21.

64. Pan JS, Awoyemi B, Xuan Z, Vohra P, Wang HT, Dyba M, Greenspan E, Fu Y, Creswell K, Zhang L, Berry D, Tang MS, Chung FL. Detection of acrolein-derived cyclic DNA adducts in human cells by monoclonal antibodies. Chem Res Toxicol 2012;25:2788-95.

65. Jia L, Wang XW, Harris CC. Hepatitis B virus X protein inhibits nucleotide excision repair. Int J Cancer 1999;80:875-9.

66. Nath RG, Chung FL. Detection of exocyclic 1,N-2-propanodeoxyguanosine adducts as common DNA lesions in rodents and humans. Proc Natl Acad Sci U S A 1994;91:7491-5.

67. Feng $\mathrm{ZH}, \mathrm{Hu} \mathrm{WW}, \mathrm{Hu} \mathrm{Y}$, Tang MS. Acrolein is a major cigarette-related lung cancer agent: preferential binding at p53 mutational hotspots and inhibition of DNA repair. Proc Natl Acad Sci U S A 2006;103:15404-9.

68. Liu XY, Zhu MX, Xie JP. Mutagenicity of acrolein and acrolein-induced DNA adducts. Toxicol Mech Methods 2010;20:36-44.

69. Yang IY, Chan G, Miller H, Huang Y, Torres MC, Johnson F, Moriya M. Mutagenesis by acrolein-derived propanodeoxyguanosine adducts in human cells. Biochemistry 2002;41:13826-32.

70. VanderVeen LA, Hashim MF, Nechev LV, Harris TM, Harris CM, Marnett LJ. Evaluation of the mutagenic potential of the principal DNA adduct of acrolein. J Biol Chem 2001;276:9066-70

71. Fu Y, Silverstein S, McCutcheon JN, Dyba M, Nath RG, Aggarwal M, Coia H, Bai A, Pan J, Jiang J, Kallakury B, Wang H, Zhang YW, Giaccone G, He AR, Chung FL. An endogenous DNA adduct as a prognostic biomarker for hepatocarcinogenesis and its prevention by Theaphenon E in mice. Hepatology 2018;67:159-70.

72. Yang JD, Malhi H. Green tea consumption: a potential chemopreventive measure for hepatocellular carcinoma? Hepatology 2018;67:10-2.

73. Arbuthnot P, Capovilla A, Kew M. Putative role of hepatitis B virus X protein in hepatocarcinogenesis: effects on apoptosis, DNA repair, mitogen-activated protein kinase and JAK/STAT pathways. J Gastroenterol Hepatol 2000;15:357-68.

74. Kudo M. Adjuvant therapy after curative treatment for hepatocellular carcinoma. Oncology 2011;81:50-5.

75. Schwartz JD, Schwartz M, Mandeli J, Sung M. Neoadjuvant and adjuvant therapy for resectable hepatocellular carcinoma: review of the randomised clinical trials. Lancet Oncol 2002;3:593-603.

76. Poon RT. Prevention of recurrence after resection of hepatocellular carcinoma: a daunting challenge. Hepatology 2011;54:757-9.

77. Izumi N. Prediction and prevention of intrahepatic recurrence of hepatocellular carcinoma. Hepatol Res 2012;42:226-32.

78. Mazzaferro V, Romito R, Schiavo M, Mariani L, Camerini T, Bhoori S, Capussotti L, Calise F, Pellicci R, Belli G, Tagger A, Colombo M, Bonino F, Majno P, Llovet JM; HCC Italian Task Force. Prevention of hepatocellular carcinoma recurrence with alpha-interferon after liver resection in HCV cirrhosis. Hepatology 2006;44:1543-54.

79. Wang SN, Chuang SC, Lee KT. Efficacy of sorafenib as adjuvant therapy to prevent early recurrence of hepatocellular carcinoma after curative surgery: a pilot study. Hepatol Res 2014;44:523-31.

80. Yoshida H, Shiratori Y, Kudo M, Shiina S, Mizuta T, Kojiro M, Yamamoto K, Koike Y, Saito K, Koyanagi N, Kawabe T, Kawazoe S, Kobashi H, Kasugai H, Osaki Y, Araki Y, Izumi N, Oka H, Tsuji K, Toyota J, Seki T, Osawa T, Masaki N, Ichinose M, Seike M, Ishikawa A, Ueno Y, Tagawa K, Kuromatsu R, Sakisaka S, Ikeda H, Kuroda H, Kokuryu H, Yamashita T, Sakaida I, Katamoto T, Kikuchi K, Nomoto M, Omata M. Effect of vitamin K2 on the recurrence of hepatocellular carcinoma. Hepatology 2011;54:532-40.

81. Yoshiji H, Noguchi R, Toyohara M, Ikenaka Y, Kitade M, Kaji K, Yamazaki M, Yamao J, Mitoro A, Sawai M, Yoshida M, Fujimoto M, Tsujimoto T, Kawaratani H, Uemura M, Fukui H. Combination of vitamin K2 and angiotensin-converting enzyme inhibitor ameliorates cumulative recurrence of hepatocellular carcinoma. J Hepatol 2009;51:315-21. 
82. Song CX, Clark TA, Lu XY, Kislyuk A, Dai Q, Turner SW, He C, Korlach J. Sensitive and specific single-molecule sequencing of 5-hydroxymethylcytosine. Nat Methods 2011;9:75-7.

83. Li S, Tan HY, Wang N, Zhang ZJ, Lao L, Wong CW, Feng Y. The role of oxidative stress and antioxidants in liver diseases. Int J Mol Sci 2015;16:26087-124.

84. Ganji SH, Kashyap ML, Kamanna VS. Niacin inhibits fat accumulation, oxidative stress, and inflammatory cytokine IL-8 in cultured hepatocytes: impact on non-alcoholic fatty liver disease. Metabolism 2015;64:982-90.

85. Xiao J, Ho CT, Liong EC, Nanji AA, Leung TM, Lau TY, Fung ML, Tipoe GL. Epigallocatechin gallate attenuates fibrosis, oxidative stress, and inflammation in non-alcoholic fatty liver disease rat model through TGF/SMAD, PI3 K/Akt/FoxO1, and NF-kappa B pathways. Eur J Nutr 2014;53:187-99. 